\title{
Good Governance and Regulatory Reform, Need Public Participation in all Development Stages in Albania
}

\author{
Prof. Assoc. Dr. Alba Robert Dumi \\ Director of Graduate School, "Ismail Qemali"Vlore University, Albania ,Management Department, \\ Email:alba.besi12@gmail.com \\ Msc Grigor Dede \\ Economy Faculty, "Ismail Qemali" Vlore, University, Albania \\ Email:grigirdede@hotmail.com \\ Ma Doklejda Roshi \\ Low Faculty, "Ismail Qemali" Vlore, University, Albania \\ Email:rosh kela@yahoo.com
}

Doi:10.5901/ajis.2014.v3n3p117

\begin{abstract}
This article sets out to examine the World Bank's efforts at strengthening good governance in Albania case study, in developing countries and improving the effectiveness of aid. It focuses on the relationship between good governance and aid effectiveness in providing a critical assessment of the Bank's approach to governance reform in developing countries. This paper scrutinizes the shifts in policies and strategies of the Bank during the 1990s as well as the research it generated to support them. The wide array of issues under "governance" occupies center stage in the development debate and the agenda of the international financial institutions (IFIs). The concept of governance captures "the manner in which power is exercised in the management of a country's economic and social resources for development" (World Bank 1992, 1). Dervish Kaptur and Richard Webb attest: "For the IFIs, the new mandate is a boost to their importance, but one fraught with peril. The new mission arrived at a moment when growing doubts regarding the purpose and effectiveness of the IFls. On matters of public administration, the Government's strategy focused on addressing two inter-related sets of interventions: (a) strengthening public financial management, including the management of both public expenditures and revenues; and (b) strengthening human resource management. On matters relating to public sector human resource management, the reform strategy envisaged addressing this issue in two major stages: civil service reform and broader public sector human resource management reform. During the first stage, the reforms aimed to create the managerial and professional nucleus required to lead any serious efforts to improve the accountability and performance of public institutions. Subsequently, in a second stage, the reform would address the larger body of public employees to improve productivity and accountability for their work and ensure that public policies, programs and services are delivered reliably and cost-effectively.
\end{abstract}

Keywords: Public financial management, HRM, Pubic sector, cost- effectively

\section{Introduction}

We want to start this paper research with definition like this:

"Justice without strength is helpless, strength without justice is tyrannical. Unable to make what is just strong; we have made what is strong just." --Pascal, Pen sees (1670)

The role of an effective regulatory regime in promoting economic growth and development has generated considerable interest among researchers and practitioners in recent years. In particular, building effective regulatory structures in developing countries is not simply an issue of the technical design of the most appropriate regulatory instruments; it is also concerned with the quality of supporting regulatory institutions and capacity. This paper explores the role of state regulation using an econometric model of the impact of regulation on growth. The results based on two different techniques of estimation suggest a strong causal link between regulatory quality and economic performance. (Jalilian H 2007)

In December 2007, the government adopted amendments to the Law on evaluation of the performance of civil 
servants. In January 2008, a new reward system for civil servants entered into force. However, turnover of staff due to political pressures has continued. The Civil Service Law regulating public administration is in place, but it is not applied systematically. The Department of Public Administration is currently drafting a strategy on public administration reform including sect oral training plans and covering local government bodies. (Gallon S 2009)

However, the role of the in ensuring implementation of the Civil Service Law and the capacity of the Training Institute of Public Administration (TIPA) remain weak. The Government worked with donors on the public financial management agenda by strengthening core public financial management units (Ministry of Finance, Supreme Audit Institute, Procurement Directorate within the Office of the Prime Minister) as well as the financial management units within each line agency (e.g., budget departments within line Ministries). (TIPA 2001 report)

\subsection{The public Administration and its development impact}

The capacity of the Department of Public Administration to steer the civil service towards an independent, merit- based and professional body needs further strengthening. The absence of sound accountability mechanisms in public administration increases the opportunities for bypassing established procedures. Appointments have continued along political party lines in contravention of the Civil Service Law. The authority of requires strengthening in order to implement the official recruitment, job classification and promotion criteria consistently. Full enforcement of the Civil Service Law and adoption of the Strategy for public administration reform will be keys to progress in this regard.

\subsection{Public sector and the independence of the civil service}

Public sector salaries were increased in July 2008. The government continues to encourage Albanian graduates of foreign universities to join the civil service. The training plan for civil servants has been revised to reflect real needs better. However, frequent replacements of civil servants are undermining the independence of the civil service and increase the opportunities for bribery of public officials. (Enlargement Strategy and Main Challenges 2008-2009)

Overall, the public administration is continuing to stabilize, but the lack of transparency and accountability in appointments is endangering its independence. What is now needed is to further strengthen public sector governance by enhancing the impartiality of public administration, a key European Partnership priority. Further progress is needed to establish an independent, merit-based, professional civil service. Since 2007, pre-accession financial assistance to Albania is provided under the Instrument for Pre-Accession Assistance (IPA). The EC allocated a total of $€ 70.7$ million in 2008. The Multi-Annual Indicative Planning Document (MIPD) for 2008 -2010 for Albania under IPA was adopted in September 2008.

Hypothesis1a. Rational persuasion is used more in an upward direction than in a downward or lateral direction.

Hypothesis $1 b$. Rational persuasion increases task commitment in all three directions.

When people gain a sense of ownership of a project, strategy, or change after participating in planning how to implement it, they are likely to be more committed to making the project, strategy or change successful (Yukl 1989). This influence tactic can be used in any direction, but it appears especially appropriate in the situation in which an agent has the authority to plan a task or project but relies on the target to help implement the plans. Because authority to assign work and make changes in work procedures is mostly downward a manager probably has more opportunity to use consultation to influence subordinates than to influence peers or superiors (Yukl \& Falbe, 1990.

Main focus areas continue to be justice and home affairs, administrative capacity-building, economic and social development and democratic stabilization. Ongoing CARDS and IPA assistance is implemented by the EC Delegation in Tirana. The management of aid on a decentralized basis is a medium-term objective for Albania. The IPA Framework Agreement was signed on 18 October 2007. Association process (SAP 2006-2007)

Tab 1. The cycle of rationality developments of hypotheses,

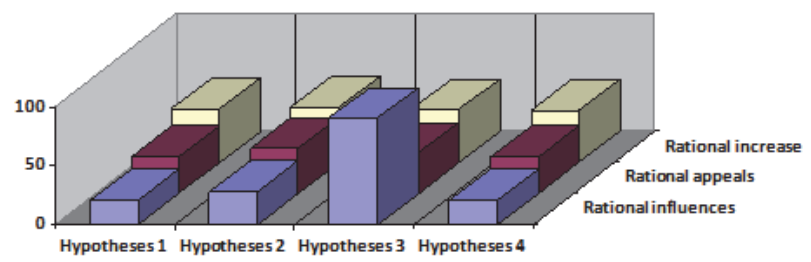

Source: Mow day, theory concepts 1978 
H 3: This influence tactic can be used in any direction, but it appears especially appropriate in the situation in which an agent has the authority to plan a task or project but relies on the target to help implement the plans

H4: The Financing Agreement for the National Programmed for 2007 under the Transition Assistance and Institution Building Component was signed on 22 January 2008 and the implementation of the programmed has started. The existence of a functioning market economy

\subsubsection{Economic policy essentials and functioning market economy}

The government submitted the Economic and Fiscal Programmer for 2007-2010 in December 2007, setting out a coherent framework for the government's economic policies. The policies continued to support the establishment of a functioning market economy, but suffered in some cases from the lack of detailed action plans. The economic strategies were broadly consistent with the current International Monetary Fund three-year 2006-2009 PRGF/EFF programmed in the country. In 2008, the government supplemented the longer-term strategy framework, adopting the National Strategy for Development and Integration (NSDI) for 2007-2013, prepared in consultation with domestic and international stakeholders. In line with the Integrated Planning System (IPS) the government also adopted the Fiscal and Macroeconomic Framework 2009-2011 and the Medium-Term Budget Programmers 2008-2010. Overall, political consensus on the fundamentals of market-oriented economic policies was strengthened, but planning at too general a level sometimes presented a risk for the implementation of economic reforms. Association process (SAP 2006-2007)

\subsection{Macroeconomic stability}

The economy experienced strong growth despite a severe drought in the summer of 2007 and continuous electricity shortages. Extensive investments and high consumption led to a 6\% growth in real terms in 2007 - the highest since 2002. Economic activity was fuelled by a robust, though slowing credit growth and continuing large-scale remittances inflows (12\% of GDP). Unreliable electricity supply continued to pose a heightened risk to sustainable economic growth. The average per capita income in 2007 was around 22\% of the EU27 average, up from 21\% in 2006. Overall, economic growth remained strong and speeded up, while the general income level remained low. External balances deteriorated, resulting in a current account deficit of 10.6\% of GDP in 2007 - up from $6.5 \%$. The deficit widened, mainly due to an increase in the merchandise trade deficit (26.8\% of GDP in 2007), in spite of strong growth in exports. Higher energy imports (30\% of the total increase in imports in 2007), resulting from a severe domestic drought, and demand for machinery contributed strongly to increase in imports.

\section{Literature Review and Hypotheses}

Merchandise exports remained more than 3.5 times lower than imports, despite a strong increase in mineral exports. The trade deficit continued to deepen in the first half of 2008 due to high imports. The surplus in services trade remained limited and surpluses of income flows and other transfers (including remittances) were lower (relative to GDP) than in the previous year. Overall, external imbalances remained high and continued to widen. Net capital inflows increased, covering the current account deficit in 2007. Net foreign direct investment reached 5.9\% of GDP in 2007 (up from 3.5\% in 2006), with strong inflows from a large-scale privatization in the telecommunication sector. Other capital inflows (mainly foreign borrowing by the private sector and non-residents' deposits) rose, reaching $3.2 \%$

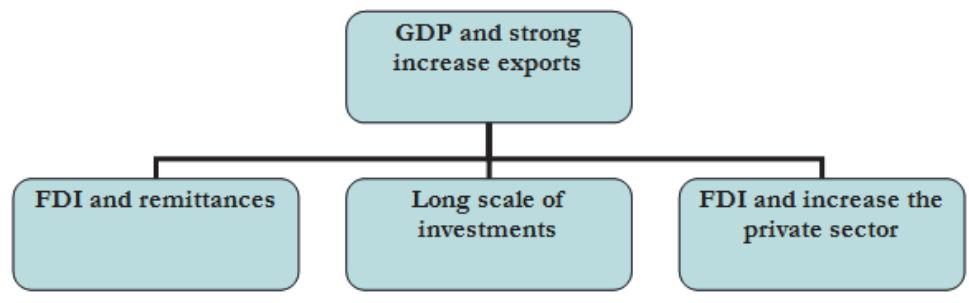

Source; Glueck, W.F. and Jauch, L. R. Business Policy and Strategic Management, 4" , McGraw-Hill, New York, 1984 


\subsection{Albanian decentralize government functions}

Albania has achieved high economic growth and has enjoyed macroeconomic stability over the past few years and average real Gross Domestic Product (GDP) growth rates of approximately six percent - the highest in South-eastern Europe - underpinned by rising exports (albeit from a low base), and continuing improvements in productivity. Maintaining this performance will be increasingly difficult; Albania will need to increase public, private and foreign investment. Above all, it will need to build human and physical capital, and improve governance structures to maintain its impressive progress to date. Association process (SAP 2006-2007) Despite GDP per capita reaching an estimated US\$3,912 (2008), poverty, high unemployment, and wide regional disparities remain daunting challenges. Institutional capacity at both, central and local levels remain among key challenges. Albania has begun to decentralize government functions, but the pace of devolution has been slower than expected due to political constraints and limited capacity at the municipal and local Government levels. Nonetheless, the decentralization process holds great promise to improve the delivery of services to the poorest Albanians, especially in health, education and water supply. The Stabilisation and Association process (SAP) with the European Union (EU) is very important to Albania. Eventual membership in the EU remains an overarching national goal; the signing of the Stabilisation and Association Agreement with the EU in June 2006 has been one of the important achievements in this direction. Association process (SAP 20062007)

Short description: Under the National Strategy for Development and Integration (Albania's EU integration framework), the Government is aligning ownership and regulation of activities in these public utility sectors, and its consumer protection framework, with European institutional and policy frameworks. The programme intends to further develop the capacities of the relevant ministries and regulatory bodies; facilitate the pro-active engagement of civil society as watchdogs to safeguard the public interest, at other times as partners helping to improve service delivery; and help to institutionalise the dialogue between suppliers and users needed to strengthen the pro-poor character of public utility regulation and consumer protection Higgins, J. M. 1983

\section{Methodology and Research Goal}

This study aims both to improve operational practices and also to help identify a strategic agenda, which is an ideal focus in developing a strategic programmed for the sector. This has the potential to raise capacity in important areas. The Albanian Government is committed to achieving balanced regional development through measures and priorities in developing public infrastructure, services and institutional reforms at the regional level.

The Government has introduced a Regional Development Cross-cutting Strategy - as part of the National Strategy for Development and Integration - to address widening disparities among Albanian regions, establish a direct linkage between budgetary resources and regional development planning and align regional development policy to EU accession. However, considerable investment is needed in almost all regions. The UN has been a strong advocate for regional development, providing assistance to building regional and local capacities for improved service delivery, planning and monitoring. Guxolli Z 2012

By 2005, all 12 regional governments of Albania formulated regional development strategies and reports. During this process, the UN promoted participatory community development to ensure people's participation in local development initiatives and the decision-making process. The UN has also supported the Regional Councils of Kukes, Vlora and Fier in development software for data collection and management for decision-making at the regional level.

The UN has been focusing assistance in Kukes, Albania's poorest region where: unemployment scores twice as high as the national average, infant and maternal mortality rates are four to five times higher than EU averages, infrastructure is poor and largely not functional and a considerable part of the natural resources are affected by the presence of landmines.

\subsection{The balanced and sustainable economic growth among the regions of Albania}

In 2005, the UN consolidated its programmers into an Area Based Development Framework with the introduction of the Kukes Regional Development Initiative (KRDI), developed based on the priorities of the Kukes population and aligned with the Regional Development Strategy. KRDI provides support in improving rural and urban livelihoods through small capital investments in rehabilitation of community infrastructure.

Priorities are identified through a wide participatory process involving the communities and local governments and focus on social services for the poorest and mine affected communities. Glueck, W.F. and Jauch, L. R 1984, Albanian 


\section{Report 2000}

The UN also provided support to the drafting process of the national Regional Development Cross-cutting Strategy. Combined UN agency support will assist the Government of Albania to realize its vision as set out in the Regional Development Cross-cutting Strategy: "a balanced and sustainable economic growth among the regions of Albania, in general and of mountainous and remote areas, in particular." The performance evaluation is mainly characterized by qualitative indicators and there are only a few quantitative indicators.

According to the data collected from the questionnaires the employees' asses the importance of the performance evaluation in concretize it with the objectivity in the evaluation to the question "Is the performance evaluation objective in your institution?"- $20 \%$ answered positively, $54 \%$ avoided the answer and $26 \%$ of them think that it is dictated from the subjectivity of the leaders. According to the questionnaire the major part of the questioned employees think that the performance evaluation takes to conflicts between the subordinate and the superiors.

\subsection{Data and methodology of study in this paper research}

When evaluations failed to meet the standard, the three most common concerns were: (1) evaluation teams received too many questions-especially questions that are too general and ill-defined-relative to the resources available for the evaluation, (2) the data collection and analysis methods were not appropriate to answer the evaluation questions, or (3) evaluation reports did not clearly demonstrate how evidence led to new findings and conclusions.

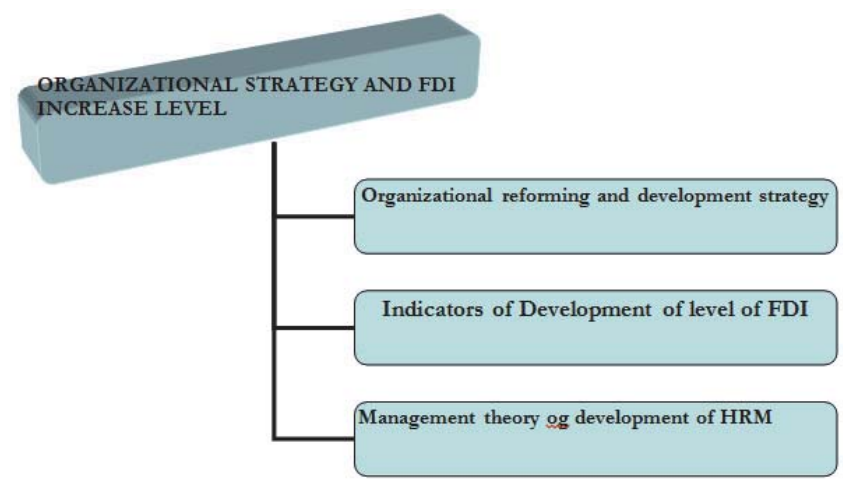

Source: Higgins, J. M. 1983" Organizational and Strategy" Management strategy" 2nd Dryden New York,

\subsection{Analyzing data}

The performance evaluation is mainly characterized by qualitative indicators and there are only a few quantitative indicators. According to the data collected from the questionnaires the employees asses the importance of the performance evaluation in $100 \%$, they concretize it with the objectivity in the evaluation. To the question "Is the performance evaluation objective in your institution?"- 30\% answered positively, $44 \%$ avoided the answer and $26 \%$ of them think that it is dictated from the subjectivity of the leaders. According to the questionnaire the major part of the questioned employees think that the performance evaluation takes to conflicts between the subordinate and the superiors. This is also another factor that contests rewarding according to the performance.

\subsection{The comprehension of the importance on the Albanian entrepreneurship.}

The field of Albanian entrepreneurship is recognized as being of fundamental importance for our economy. In this framework, it's very important understanding or forecasting the entrepreneurial act and its success or failure, and defining more accurately the environmental conditions favorable to that act. A key element in the field of entrepreneurship is the dialogic between individual and new value creation, within an ongoing process and within an environment that has specific characteristics. This definition emphasizes the fact that we will always not understand the phenomenon of entrepreneurship if we do not consider the individual (the entrepreneur), the project/devoir, the environment and also the links between them over time. Higgins, J. M. 1983 
The implementation of the strategy involves all the working groups in planning, designing, conducting product or service, development, evaluation and marketing in the accomplishment of its mission. If during the process of implementing the strategy, the strategy chosen is not able to overcome the difficulties arising from the external or internal shortcomings in the company then the company can change the strategy, choosing one of the alternative scenarios defined in a strategic SWOT analysis carried out above to overcome difficulties and facilitate the work of all groups to achieve their goals in fulfilling the mission. Glueck, W.F. and Jauch, L. R 1984

\section{Figure 3}

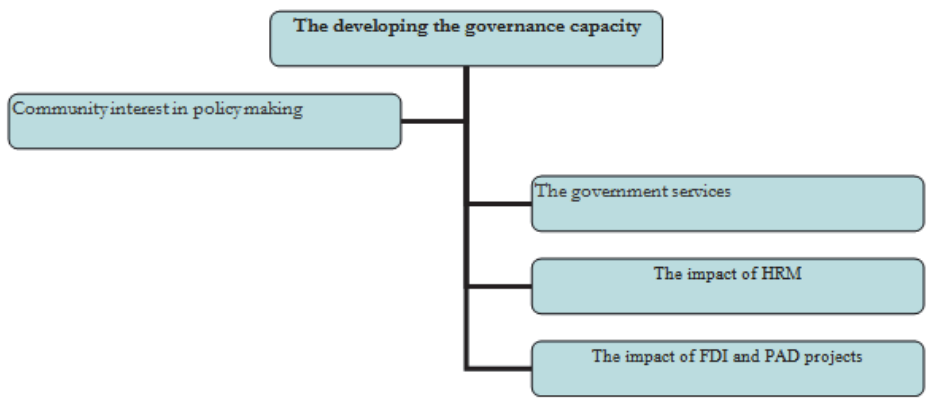

Bradler\& Sediss, Individualism and organizational behavior, USA Company: Kingston, Ontario, $1989 .{ }^{1}$

\section{Finding and Results of this Paper Research}

The problem lies in policies that respond to the bond market but virtually exclude any other community interest in policy making. It is recommended that openness in government and allowing taxpayers to understand government services are essential goals in ensuring responsible citizen oversight and providing taxpayers the opportunity to be less likely to propose restrictive initiatives or force dramatic political or management changes through the electoral process or bond referenda. Despite good progress in those areas, Albania needs to do more to improve its ranking in other indicators. In addition, much remains to be done because the report doesn't measure other important indicators that have significant impact on the business climate like corruption, infrastructure and the efficiency of the public administration.

\subsection{Resolve the problems of Albania's economic, developing the governance capacity.}

The financial collapse in 1997 was a watershed event in Albania's transition from its communist past. It highlighted the problems of Albania's economic governance capacity and, from an administrative standpoint, reaffirmed and highlighted the inefficacy of a public administration, unable to enforce its laws and regulations. As the public's confidence in Albanian institutions had been significantly eroded by the recent events, restoring the public's trust in the government became the main priority of the government. In order to achieve this objective the capacity of the public administration needed to be dramatically strengthened

\section{Conclusions and Recommendations}

The expected results of this research consist on realizing the following conclusions:

The importance of innovation as such for the future of the sector was strongly emphasised by policy makers responsible for forestry in all Central European countries. Current innovation support is piecemeal, fractioned and often not co-ordinated. This issue-by-issue approach foregoes the benefits of a more coherent and comprehensive approach; there is support for new approaches and ideas. It would considerably strengthen the development of an innovation and entrepreneurial oriented climate. Higgins, J. M. 1983

\footnotetext{
1 Tilles, S. "How to Evaluate Corporate Strategy", Harvard Business Review, 41,4, 111-21. Organizational Management "Department of the Environment, London 1990.De Soto, Herminie; Overseas Private Investment Corporation, 1100 New York Ave., NW Washington, The assessment of the affects of certain public and private projects on the environment", pg 123-129 Official Journal of the USA
} 
For the purpose of strengthening innovation and entrepreneurship and the promoting of financial system in the different sectors it is therefore recommended to develop an explicit innovation policy, strategy or programme. When developing innovation policies, strategies or programmes, it is important to consider each of the three main functions of an innovation system separately and as a comprehensive whole. The most important areas to cover and the main areas for improvement are the following:

- Provide Information on New Markets and Improve Information Flows;

- Include a Cross- Dimension in the Management of Conflict and Coordination;

- Provide Incentives that Systematically Innovation in the field.

- In the field of entrepreneurship, the classical positivist paradigm and constructivism can exist side by side, as they do in the field of strategic management.

The field of entrepreneurship, and in particular the study of its archetype is undoubtedly one of the most complex in the social sciences.Albania has made real progress towards replacing the highly centralized political system inherited from communist times with one that gives real authority and autonomy to Albania's local governments.

\section{References}

Glueck, W.F. and Jauch, L. R. Business Policy and Strategic Management, $4^{\text {th }}$, McGraw-Hill, New York, 1984 Higgins, J. M. 1983" Organizational and Strategy" Management strategy" 2nd Dryden New York, Hofer, C, W. and Schendel D 1983, Strategy Formulation: Analytical Concepts, West, St Paul, "Industrial Performance Analysis, 1987-1988 ICC "Business Policy and Management Capacity," 2nd Irwin, Homewood, IL, 1985. Tilles, S. "How to Evaluate Corporate Strategy", Harvard Business Review, 41,4, 111-21.

Organizational Management "Department of the Environment, London 1990.De Soto, Hermine; Overseas Private Investment Corporation, 1100 New York Ave., NW Washington, The assessment of the affects of certain public and private projects on the environment", pg 123-129 Official Journal of the USA

Newman E. H. Constructive Control: Design and Use of Control Systems, Prentice Hall, Englewood Cliffs, Nj.1975.

Higgins, J. M. "Organizational Policy and Strategic Management of Water", 2 $2^{\text {nd }}$ den, Dryden New York, 1983

Hofer, C, W. and Schendel, D, Dtrategy Formulation: Analytical Concepts, West, St Paul, MN, 1983.

Industrial Performance Analysis, 1987-1988 edn, ICC Business Policy and Management Hedrick Capacity,2nd edn Irwin, Homewood, IL,1985.

Glueck, W.F. and Jauch, L. R. Business Policy and Strategic Management, th $^{\text {th }}$ edn, McGraw-Hill, New York, 1984

Bishop,E. B. "ROCE as s Tool for Planning and Control", Long Range Planning, 2,4, 1969, 80-7.

Tilles, S. "How to Evaluate Corporate Strategy", Harvard Business Review, 41, 4, 1963, 111-21.

Commission of the European Communities, "Council directive of 27 June 1985 on the assessment of the affects of certain public and private projects on the environment", in Official Journal of the European Communities, L175, pages 40-48. 